„Bohemistyka” 2020, nr 1, ISSN 1642-9893

Marcin FILIPOWICZ

DOI: $10.14746 / b o .2020 .1 .1$

Uniwersytet Hradec Králové

\section{Emigracja jako czynnik konsolidacji i rewizji kobiecego projektu tożsamościowego. Węgierskie doświadczenia Boženy Němcovej}

Keywords: Czech literature, travel journal, emigration, Austro-Hungary, Božena Němcová

Słowa kluczowe: literatura czeska, dziennik podróży, emigracja, Austro-Węgry, Božena Němcová

\section{Abstract}

In the 1850's the Austrian authorities repressed some Czech national activists, which in many cases lead to voluntary or forced exile. This was also the case for Božena Němcová's husband Josef. In 1851 due to his awareness of changes in the political climate and forthcoming persecutions he decided to apply for relocation to Hungary. The paper focuses on Němcová's correspondence with her husband as well as her travel journal (The Memories of the Hungarian Journey - 1854) and considers the following question. Was her constant refusal to go into exile an important moment for creating her female self?

W latach piećdziesiatych XIX wieku austriackie władze zastosowały represje wobec niektórych działaczy czeskiego ruchu narodowego, co w wielu przypadkach prowadziło do dobrowolnej lub przymusowej emigracji. Dotyczyło to również męża Boženy Němcovej - Josefa. W 1850 roku, majac świadomość nadchodzącej zmiany klimatu politycznego, zdecydował sie złożyć podanie o przeniesienie na Wegry. Artykuł koncentruje się na korespondencji pisarki z tego okresu oraz jej dzienniku podróży (Vzpominky z cesty po Uhř́ch - 1854) i próbuje odpowiedzieć na następujące pytanie, czy opór pisarki wobec konieczności udania się na emigrację stanowił istotny moment w kształtowaniu się jej kobiecej tożsamości?

Powstałe na gruncie gender studies opisy dziewiętnastowiecznej twórczości kobiecej bardzo często kładły nacisk na problematyke tożsamości płciowej. W przypadku mniejszych środkowoeuropejskich grup etnicznych owe kobiece projekty tożsamościowe wchodziły zazwyczaj w intensywne interakcje $\mathrm{z}$ rodzaca się ideologia narodową (Blom, Hageman, Hall 2000). W badaniach tych jednak nie podnoszono zbyt często kwestii dziewiętnastowiecznych ruchów emigracyjnych jako czynnika wpływającego na procesy kształtowania się nowoczesnych tożsamości płciowych. Podobnie też było w przypadku badań nad twórczością Boženy Němcovej, której konfrontacja z koniecznością emigracji pozostawała do tej pory na marginesie badawczego zainteresowania. Dotychczasowa literatura przedmiotu doświadczenie potencjalnej emigracji pisarki sprowadzała do czechosłowacystycznie interpretowanych podróży pisarki na Słowację (Górne Węgry), podczas których Němcovą interesowało przede wszystkim odkrywanie piękna słowackiej kultury (Haluznický 1952, Frajkovská 2011). Dlatego też moim celem będzie przyjrzenie się temu istotnemu - choć krótkiemu - doświadczeniu z życia pisarki i zbadanie jego potencjalnego wpływu na poszukiwanie przez nia odpowiedzi na pytania o to, kim jestem jako kobieta, czego pragnę i do czego dążę.

\section{Trochę nieoczywista emigracja}

Božena Němcová osiągnęła szczyt swojej aktywności twórczej w połowie lat pięćdziesiątych XIX wieku. Ten okres w historii monarchii habsburskiej jest często określany jako dekada neoabsolutyzmu, która charakteryzowała się przemiana monarchii w państwo wysoce scentralizowane i oparte na kulturze niemieckiej (Johnston 1983, s. 45-50). Z jednej strony oznaczało to intensywne stłumienie rodza/ cych się ruchów narodowych, w tym również czeskiego. Dlatego też austriackie władze wprowadziły w tym czasie represje wobec co bardziej radykalnych czeskich działaczy odrodzeniowych, które nierzadko prowadziły do dobrowolnej lub wymuszonej emigracji. I chociaż nie było to powszechne zjawisko, to jednak wpisało się na trwałe w czeską świadomość historyczną. Z drugiej jednak strony jest to okres budowania nowoczesnego państwa, a tym samym szansa dla wielu podrzędnych czeskich urzędników do zrobienia kariery w innych czę- 
ściach monarchii. Jednocześnie w okresie tym zauważalny jest ogólny wzrost mobilności spowodowany rozbudową sieci kolejowej między głównymi ośrodkami miejskimi w cesarstwie austriackim (Pokorná 2004, s. 9).

Warto zauważyć, że emigracja nie musiała w tym przypadku koniecznie oznaczać opuszczenia monarchii. Przeniesienie się z jednej części wieloetnicznego imperium do drugiej stanowiło często dla migrujących osób trwałe oderwanie się od swojej wspólnoty kulturowej. Rzeczywistość austriacka XIX wieku każe również dokonać rewizji pojęcia emigracja. W dzisiejszym powszechnym rozumieniu chodzi o opuszczenie przez jednostkę bliskiej jej kulturowo przestrzeni jednego kraju, w ramach którego obowiązuje swoboda przemieszczania, i osiedlenie się w innej przestrzeni kulturowo-państwowej. W Austrii połowy XIX wieku te wstępne założenia można zasadniczo odnieść do zmiany miejsca zamieszkania $w$ ramach samej monarchii. Po pierwsze, swoboda podróżowania po kraju była mocno ograniczona. O wydanie dokumentów podróży trzeba było występować do władz za każdym razem, kiedy się chciało opuścić miejsce stałego pobytu i uzasadnić to niezbędną koniecznością podróży. Po drugie, austriacki poddany musiał ubiegać się o dwa typu dokumentów: jeden obowiązujący na terenie danej części składowej monarchii, drugi wydawany przez organ administracyjny wyższego stopnia w przypadku podróży do innej części kraju (Pokorná 2004, s 10). Dlatego też z dzisiejszego punktu widzenia przeprowadzenie się między dwoma odmiennymi etnicznie, kulturowo i administracyjnie jednostkami składowymi państwa Habsburgów wypełnia zasadniczo znamiona emigracji.

W takich warunkach historycznych mąż pisarki Josef Němec, który był urzędnikiem podatkowym, zdecydował się wyjechać z Czech na Węgry. Przez swoich przełożonych był określany jako dobry urzędnik, ale jednocześnie jako „Ultraczech”. W 1851 roku, będąc świadomym zmiany klimatu politycznego oraz potencjalnych represji, zdecydował się złożyć wniosek o przeniesienie. Liczył też na szybszy awans w strukturach administracji podatkowej. Jego żona, pod- ówczas już znana pisarka, zdecydowała się pozostać w Czechach. Ostatecznie w 1853 roku polityczna przeszłość z okresu przedrewolucyjnego dopadła Józefa na Węgrzech. Kiedy już bowiem Božena pod wpływem społecznego nacisku ostatecznie zdecydowała się przeprowadzić (Pokorná 2004, s. 13-14), władze austriackie wszczęły przeciwko niemu postępowanie dyscyplinarne, w wyniku którego został usunięty z urzędu i Němcovie musieli wracać do Czech. Przez ponad dwa lata jednak małżonkowie żyli w swoistym rozkroku między Pragą, gdzie mieszkała Bożena z dziećmi, a Miszkolcem (dzisiejsze Węgry) i Balaškimi Ďarmotami (dzisiejsza granica słowacko-węgierska), gdzie przebywał jest mąż. Pozostawali jednak w ścisłym kontakcie listowym, a pisarka kilkukrotnie odwiedziła męża na Węgrzech. Przez ponad dwa lata musiała się zatem konfrontować z samą koniecznością emigracji, jak też odmiennością węgierskiego środowiska kulturowego, w którym miałaby się odnaleźć.

W swojej analizie zamierzam skupić się na korespondencji Němcovej z tego okresu oraz na jej dzienniku podróży Vzpomínky z cesty po Uhřich wydanym w 1854 roku. Chciałbym zastanowić się nad następującymi pytaniami. Czy kontakt z odmiennym stylem życia mógł wpłynąć na jej etniczną, kulturową oraz płciową tożsamość? Czy opór przed wyjazdem na Węgry stanowił istotny moment dla kształtowania się jej kobiecego ,ja”? I w końcu, czy emigracja mogła być dla Němcovej czynnikiem uruchamiającym proces emancypacji wobec męża?

\section{Model kobiecej tożsamości i dziennik podróży}

W czeskim piśmiennictwie XIX wieku wytworzył się specyficzny model kreowania kobiecej tożsamości odpowiadający męskiemu zapotrzebowaniu na kobietę zaangażowaną w ruch odrodzenia narodowego. Dyskurs narodowy wyprodukował ideał czeskiej patriotki, według którego czeska kobieta powinna była być wszechstronnie wykształconą matką i strażniczką domowego ogniska, przyczyniającą się do edukacji nowych pokoleń patriotów i pomnażania majątku na- 
rodowego. Ideał ten jest chyba najlepiej widoczny właśnie we wczesnych wierszach Boženy Němcovej publikowanych w połowie lat czterdziestych (Filipowicz 2008, s. 155). Czy jednak doświadczenie emigracji zrewidowało te programowe patriotyczne założenia? Czy z korespondencji pisarki oraz ze wspominanego dziennika podróży nie wyłania się obraz znacznie większej kobiecej niezależności, uruchomiony właśnie przez doświadczenie mierzenia się z sytuacją emigracji?

Powinniśmy zwrócić jeszcze uwagę na sytuację pisania dziennika podróży. Jest to bowiem specyficzny gatunek literacki, za którego podstawową cechę dystynktywną uznaje się temat oparty na zewnętrznym fakcie podróżowania, rozumianym jako proces poznawczy (Dominte 2016, s. 139-144). Jego istotą jest z kolei spotkanie podróżującego podmiotu z nieznaną rzeczywistością, przy czym nie jest ważne napięcie geograficzne, ale kulturowo-cywilizacyjne, które zachodzi między podróżnikiem a nową przestrzenia. Wiąże się z nią też koncepcja podmiotu narracyjnego - medium, które integruje zewnętrzne poznanie $\mathrm{z}$ informacją o sobie, czyli łączy w swojej opowieści informację o obiektywnym świecie z raportem o własnym stanie ducha. Sytuacja przestrzennego wyobcowania stanowi dla podmiotu narracyjnego wyzwanie, prowokujące do ciągłego porównywania opisywanego ,tutaj” (zazwyczaj nieznanego, nowego i obcego) z przywoływanym w pamięci „tam” (znanego i swojskiego). Pozostaje on zatem w napięciu ciągłego określania się wobec obu przestrzeni, a także ciągłego określania własnej tożsamości (Kozicka 2003, s. 78-79). Dlatego też interesujący mnie tekst literacki jest dobrym polem obserwacyjnym dla zbadania elementów potencjalnej przemiany tożsamościowej wywołanej koniecznością konfrontacji z obcą przestrzenią kulturową.

\section{Węgry i Węgrzy}

Zaczać należy od nastawienia pisarki do miejsca potencjalnej emigracji. Jej pojęcie o Węgrzech przed wyjazdem męża było raczej nikłe, natomiast jego pierwsze listy nie sprzyjały budowaniu pozytywnemu wizerunku kraju, dokąd miałaby się ewentualnie przeprowadzić. Już 3 stycznia 1851 roku, zaraz po przyjeździe z Pragi do Miszkolca, pisał do żony, że każdemu odradzałby przeprowadzkę, jest to bowiem dziwny i zapóźniony cywilizacyjnie kraj, który w ogóle mu się nie podoba:

Mužeš si pomyslit, jak jsou zde pošty zřízeny, když se člověk asi 20 mil cesty tak dlouho tlouct musí, a na ten způsob máš tu všecko tak (Němcová 2003, s. 163).

Ogólnie z listów od męża z tego pierwszego okresu nie wynika wprost, żeby naciskał na żonę, by jak najszybciej przeprowadziła się na Węgry. W warstwie deklaratywnej jest wręcz przeciwnie. Josef Němec pisze do Boženy, że na pewno nie spodobałoby się jej tutaj i że sobie nawet nie wyobraża, żeby mogła przyjechać, podróż bowiem jest strasznie droga (Němcová 2003, s. 164-165, 167). Jednocześnie jednak w wielu listach Němca przebija się rzeczywista i szczera, a nie konwencjonalna i typowa dla dziewiętnastowiecznej epistolografii tęsknota za żoną. Narzeka na rozłąkę, pisze o odczuwanym smutku i o niemożliwości normalnego funkcjonowania w stanie kompletnego osamotnienia (Němcová 2003, s. 166, 179). Można to zatem uznać za formę pośredniego i emocjonalnego nacisku na żonę. Należy oczywiście postawić sobie pytanie, czy Němcová nie odczuwała podobnej tęsknoty za mężem, która motywowałaby ją do uczynienia wszystkiego, żeby jak najszybciej do niego dołączyć. Nie mamy wprawdzie do dyspozycji stosownego materiału badawczego, który mógłby nam pomóc znaleźć odpowiedź na to pytanie, ponieważ wszystkie listy pisarki do męża z tego okresu zostały zarekwirowane przez austriacką policję, i nie wiemy, czy pisała do niego w podobnym duchu. Pozostają nam wyłącznie dowody pośrednie, które wskazują na to, że nie odczuwała zbytniego dyskomfortu z powodu rozłąki. Po pierwsze, w całej jej zachowanej korespondencji z 1851 roku, nawet tej najbardziej intymnej z przyjaciółkami, nie odnajdziemy ani śladu wyrażania głębokiej tęsknoty za mężem. O jego pobycie na Wegrzech pisze rzeczowo i nie dołącza do tego nawet skonwencjonalizowanej afektacji, a w dodatku 
nie wyraża się o nim inaczej niż Němec. Co więcej, w jej listach do znajomych z przełomu 1851 i 1852 roku, kiedy mąż przyjechał na jakiś czas do Pragi, odnajdujemy drobne wskazówki świadczące o tym, że realne i codzienne pożycie małżonków nie należało do najłatwiejszych. W eufemistyczny sposób pisze siostrom Rottovym o awanturach czy też o tym, że pójdzie z mężem do teatru, jedynie jeżeli dołączą przyjaciółki (Němcová 2003, s. 222). Z kolei Johanna Mužáková (późniejsza pisarka Karolína Světlá) 7 marca 1853 roku pisze do Němcovej, że chętnie by ją odwiedziła, ale zapewne w domu straszy Němec (Němcová 2004, s. 29). Innymi słowy na podstawie zachowanej korespondencji można się domyślać, że sytuacja wyjazdu męża, nawet w obliczu pozostania samej w Pradze z dziećmi, była dla pisarki raczej komfortowa.

Mamy zatem do czynienia z następującym punktem wyjścia, zanim jeszcze doszło do zetknięcia się kobiecego podmiotu $\mathrm{z}$ emigracyjną przestrzenią kulturową: obraz Węgier rysujący się w listach od męża nie jest zachęcający, a relacja z nim samym nie stanowi dostatecznej motywacji do stworzenia pozytywnego nastawienia do nowego kraju, które przełożyłoby się na rzeczywistą chęć wyemigrowania. I rzeczywiście, Němcová nie wyrabia sobie najlepszego zdania o Węgrzech. Już w trakcie pierwszej podróży jej postrzeganie nowego kraju jest zdecydowanie negatywne. W liście do Antonína Klementa z czerwca 1851 roku pisze:

[...] ale jsou dalece pozadu ti Mad'aři [...] ovšemže také suroví a zdivočili jsou“ (Němcová 2003, s. 187).

Nie bardzo jednak wiadomo, na podstawie czego konstruuje swoje daleko idące sądy. Niewątpliwe w jej ocenie Węgrów wyraźnie pobrzmiewa popularne w Czechach w pierwszej połowie XIX wieku przekonanie o tym, że język i narodowy charakter są nierozerwalne (Leerseen 2006, s. 97-101, 122-126, 177-185; Hroch 2009, s. 82-94). Było ono ukształtowane pod wpływem Herderowskiego i Humboldtowskiego rozumienie języka jako wyrazu charakteru narodowego, w ramach którego język przestał być neutralnym środkiem komunika- cji, ale stał się ,,skarbnicą” zwyczajów, moralności, losów historycznych oraz aspiracji danej wspólnoty (Loužil 2005, s. 642). Dla wychowanej i żyjącej w dwujęzycznej czesko-niemieckiej przestrzeni Czech pisarki zetknięcie się z nienależącym do grupy języków indoeuropejskich węgierskim stanowiło więc rodzaj szoku, co było dostatecznie silnym powodem, żeby negatywnie oceniać użytkowników tego w domyśle „barbarzyńskiego” języka.

Jest raczej mało prawdopodobne, żeby pisarka w trakcie pierwszej podróży na Węgry zgłębiła zawiłości węgierskiej leksyki. Nie stanowiło to jednak dla niej przeszkody, żeby we Vzpomínkách z cesty po Uhřich wypowiedzieć się na temat węgierskich wulgaryzmów i od razu połączyć ich występowanie z węgierskimi cechami narodowymi:

Nikdo ale snad na světě nezná více hřešit, proklínat, než Mad’ar, pro to má tolik původních hrozných slov, že se mu z úst řinou jako rachot hromu [...]. Mad'ar je hrubých mravi̊, prchlý, a kdo ho rozvhněvá, běda mu, odpustit nezná tak brzy; [...] $\mathrm{k}$ práci ale lenivý a s výmysly prospěšnými, důvtipnými hlavu si pranic netrápí [...]. Pravá povaha jeho ale není hrdinská, ba spíše povolná až k bojácnosti naklaněná (Němcová 1955, s. 43).

Ocena węgierskiego charakteru narodowego nie bierze się wyłącznie z pobieżnego kontaktu z językiem węgierskim. Jest ona raczej pochodną ogólnej oceny Węgier jako kraju o znacznie niższym poziomie rozwoju cywilizacyjnego niż Czechy. Narratorce dziennika podróży przede wszystkim rzuciły się w oczy brud, bałagan i złe warunki higieniczne:

[...] špatná večeře a ještě se špatnějším noclehem v špinavé jízbě; Rozsáhlý park, ale všecko zanedbáno; nízká stavení [...] když se dovnitř podívá, není žádného pohodlí, ani souměrnosti ani vkusu. Stavení jsou z bláta vystavěna [...] domky malé, okénka $\mathrm{v}$ nich o málo větší než dlaň, která za celý rok se neotevřou takže člověka puch ztuchliny až zaraží [...] podlaha je utlučený mlat [...] po dvoře a po zahradě takový zvláštní nepořádek, který se jen Mad'aru líbit může. Všecka nečistota z domů stéká bud' po stružkách aneb se vynáší na ulici do velkých louží, jichž bývá v ulici po dvou i třech; taktéž se všecko smetí shází na ulici a všechny zdechliny [...]. Uherské bláto je světoznámé, ale kdo ho neviděl, ten si o něm nemůže udělati ponětí; Smutné jest, že se neuznává, že [...] jsou příčinou rozličných tam nemocí; zvlášt' když se to paří, z jara, je tam takového zápachu po ulicích, až hlava bolí (Němcová 1955, s. 15, 23). 
Wprawne oko obserwatorki, przyjeżdżającej z bardziej zaawansowanej cywilizacyjnie części monarchii, pozwoliło jej też dokonać oceny sposobu organizacji przestrzeni publicznej. Przejeżdżając przez Peszt, zauważa wprawdzie jego pozytywne aspekty, jak np. przestronny i czysty dworzec kolejowy, szerokie place oraz piękne budynki użyteczności publicznej. Jednak to pozytywne wrażenie jest zdominowane przez obserwację licznych walących się chałup i brudnych karczm. Ogólnie zatem stwierdza, że w Peszcie zdecydowanie najlepiej jest patrzeć na Dunaj (Němcová 1955, s. 12-13). W dalszej części tekstu pierwsze negatywne wrażenie już tylko się utrzymuje:

Hatvanye, městečko mad’arské vystavené naskrz z blátových cihel; Miškovec [...] je rozsáhle, ale nepořádně stavěné město (Němcová 1955, s. 16-21).

Zdecydowanie jednak brakuje jej publicznej przestrzeni służącej do rekreacji, co powoduje, że miejscowa ludność wysiaduje na brudnych ulicach w smrodzie, kurzu i żarze słonecznym (Němcová 1955, s. 23-24). Warto tu zaznaczyć specyfikę kobiecej pespektywy, ponieważ Němcová ewidentnie ocenia Węgry pod kątem możliwości zdrowego i bezpiecznego wychowania młodszych dzieci. Ocena ta ze zrozumiałych względów nie jest pomyślna.

Kolejną kwestią, która stosunkowo często pojawia się w listach i dzienniku podróży Němcovej, jest sposób podróżowania, a ściślej rzecz ujmując, zacofanie komunikacyjne panujące w tym kraju. Z jednej strony wydaje się to poniekad dziwne, ponieważ tradycyjnie z kobiecą perspektywą nie wiąże się zainteresowania taką problematyką. $\mathrm{Z}$ drugiej jednak strony przy odbyciu tak długiej i męczącej podróży wszelkie nadmierne uciążliwości dla podróżującego musiały być intensywnie odczuwane i stać się w naturalny sposób obiektem obserwacji i oceny. Po przejechaniu węgierskiej granicy i dotarciu do Pressburga narratorka dziennika odnotowuje, że wagony węgierskich pociąów są szerokie, wygodne i dobrze wyposażone (Němcová 1955, s. 11). Potem jednak jest już dużo gorzej, stan dróg i pojazdów narratorka ocenia jako bardzo zły, co też z pewnością nie zachęcało do emigracji:
Naše ekvipáže, patřila vlastně k zemanským, ačkoli byla velmi nepěkná [...] má as tu podobu jako řeznický vozík v Praze; jedeme [...] na vozech velmi bídných, střeseme se tedy řádně na té cestě; zde to ale jinák není, a musí být člověk spokojen, když nemusí jet na hnojníku (Němcová 1955, s. 14).

\section{Węgierki}

W kontekście wpływu konfrontacji z węgierską przestrzenią kulturową na kształtowanie własnej kobiecej podmiotowości najważniejszy wydaje się kontakt z węgierskimi kobietami. Zanim jednak przejdę do analizy znaczenia obrazu Węgierek, jaki po sobie pozostawiła Němcová, konieczne będzie przyjrzenie się podmiotowej samoświadomości, jaką w czasie wyjazdu na Węgry miała pisarka. Wspominałem już o modelu narodowej kobiecości tworzonym przez czeski dyskurs narodowy, do którego umacniania literacka twórczość Němcovej niewątpliwie się przyczyniała. W życiu prywatnym, jak to zazwyczaj bywa, dyskursywne normy kobiecości pisarkę mocno uwierały. $Z$ jednej strony na przełomie lat czterdziestych i pięćdziesiątych była już uznaną osobowością literacką, intensywnie uczestniczącą w intelektualnym i artystycznym życiu praskiej elity narodowej. Powodowało to, że miała zdecydowanie rosnace aspiracje emancypacyjne, także w zakresie pozamałżeńskich relacji intymnych. Na przykład w liście do przyjaciółki Veroniki Vrbíkovej ze stycznia 1851 roku pisała:

[...] co ti mužšśí o mé osobnosti soudí, to nebudu Ti opakovat, ti nás obyčejně obelhávají, jednou z nás andělé, jednou d'ably tvoří, [...] mohlo z nás být něco jiného, kdybychom měly lepší zř́izené školy (Němcová 2003, s. 169).

Z drugiej jednak strony jako wychowana w mieszczańsko-austriackiej kulturze Czeszka była nieustannie poddawana presji bycia doskonałą gospodynią domową, w której to roli bardzo źle się sama odnajdywała. W liście do Jana Helceleta pisała, że czuje się w tej roli jak pozbawiona duszy maszyna (Němcová 2004, s. 141).

Opis Wegierek można zatem potraktować jako zwierciadło, w którym odbija się własna kobieca tożsamość obserwatorki. Jak się można 
domyślać, nie zawiera on, podobnie jak w przypadku innych elementów węgierskiej rzeczywistości, pozytywnego wartościowania, które mogłyby stanowić inspirację do naśladowania. Němcová w swojej narracji tworzy modelową figurę węgierskiej kobiety, stanowiącą źródło różnicy. W dużej mierze pełni ona rolę konsolidatora własnej tożsamości. W przypadku większości cech węgierskich kobiet jest to konsolidacja poprzez negację. Pojawiają się jednak elementy, które stanowią dla Němcovej uzasadnienie dla własnego przekraczania granic narzucanego jej modelu kobiecości.

Pierwszym elementem, który chciałbym wziąć pod uwagę, jest wygląd. Węgierki zdaniem Němcovej są wyrośnięte, ale pozbawione pięknych i zaokrąglonych kobiecych kształtów. Uwielbiają biżuterię i krzykliwe ubrania, jednak ich włosy sa tak tłuste, że aż z nich kapie. Zresztą nie tylko włosy, całe smarują się słoniną. Ten politowania godny obraz dopełnia wyraz ich twarzy - pochmurny i obojętny (Němcová 1955, s. 17, 41, 45). Na podstawie tego opisu można stwierdzić, że narratorka konsoliduje w sobie przekonanie o naturalnym i skromnym kobiecym pięknie, które jednak musi spełniać podstawowe standardy higieniczne. Co więcej, nie może ono opierać się wyłącznie na kobiecej fizyczność, lecz musi także stanowić odzwierciedlenie stanu ducha, który ujawnia się w wyrazie twarzy. Tu dochodzi kolejny element oceniany przez narratorkę nader krytycznie, a mianowicie stosunek Węgierek do sfery duchowo-intelektualnej:

Paní sedí ve svém pokoji, baví se bud’ ženskými pracemi, bud’ je-li velmožná, nějakými titěrkami, nebot' čtení a duševní takové zábavy jen některá miluje, podívá se po zahradě, poklepá si v parádním pokoji, když přijdou návštěvy, strojí se $\mathrm{k}$ polednímu, po obědě pospí, a tak ujde př́ijemně čas (Němcová 1955, s. 41).

Można zadać pytanie, czy powyższy opis znacznie odbiegał od kondycji intelektualnej praskich mieszczanek. Raczej nie, one również powszechnie uznawały kupowanie książek i czasopism za marnotrawstwo, a swoje rozmowy koncentrowały głównie wokół ubrań, bezczelności służby i pikantnych plotek (Světlá 1880, s. 129-130). Jednak tu w konfrontacji z obcym elementem narodowym dochodzi do konsolidacji emancypacyjnego elementu kobiecej tożsamości.
W interesujący sposób przedstawia się również podejście narratorki dziennika podróży do sposobu prowadzenia przez węgierskie kobiety gospodarstwa domowego. Ujawnia się w nim bowiem swoista ambiwalencja uczuć wobec transgresji silnie zinternalizowanej mieszczańskiej normy kulturowej. Jak już wspominałem, rola gospodyni domowej Němcovą mocno ograniczała i szczerze nie lubiała tej części wzorca kobiecości. Kiedy jednak styka się z odmienną węgierską normą, która nie wymaga od kobiet pełnego utożsamienia się z prowadzeniem gospodarstwa domowego, konstruuje swoja narrację w tonie wyższości i dumy z posiadania praktycznych kobiecych umiejętności:

[...] zavaření ovoce [...] tot' jediné odvětví hospodářství, jemuž se rády věnují; v domácnosti vede se všecko hlučně a bohatě; jen trochu možná paní musí mít „kuchárku“ [...]. Co jen trochu možný dům je, tam se nestará paní o hospodářství [...] poručí, co se bude vařit, ale do kuchyně nejde se podívat, to by věru hanba bylo. Velice se tomu divily, že u nás i vznešené paní se nestydí v čas potřeby jít do kuchyně vařit a že vařit umí. [...] U nás [...] hledí se vždy na jakost jídel, zde na mnohost" (Němcová 1955, s. 26, 41-42).

Widzimy zatem, że główną wadą Węgierek jest nieumiejętność gotowania. Położenie tak dużego nacisku na ten aspekt obcej kulturowej codzienności może chyba świadczyć o próbie kompensacji własnych niedociągnięć $\mathrm{w}$ tej sferze.

Również stosunek węgierskich kobiet do życia rodzinnego i wychowania dzieci poddany jest krytycznej ocenie:

Mad’arky nemají mnoho dětí, obyčejně dvě, tři, a na těch nevisí s velkou láskou a pečlivostí [...] není rodinný poměr tak srdečný a útulný, jak by měl být (Němcová 1955, s. 45).

Na podstawie powyższego fragmentu można odtworzyć różnicę kulturowa w podejściu do roli matki. Widać, że do mieszczańskiej kultury Czech przenikał już wtedy z Zachodu dyskurs o sakralnym wręcz charakterze miłości macierzyńskiej. Jak pisze Elisabeth Badinter, wiek XIX zaczął bez końca wysławiać słodycze macierzyństwa, które przestało być traktowane jako narzucony obowiązek, a stało sie zajęciem godnym największej zazdrości i najmilszym, jakie mogłaby 
sobie wyobrazić kobieta (Badinter 1998, s. 128). Ewidentnie oddziaływanie tego dyskursu na Węgrzech nie było jeszcze zbyt silne, dlatego też Němcová mogła w konfrontacji z Węgierkami skonsolidować również ten element swojej kobiecej tożsamości.

Ostatnią już kwestią, którą narratorka w odniesieniu do węgierskich kobiet zauważa, to ich znacznie luźniejsza niż w Czechach obyczajowość seksualna. Pisze mianowicie:

[...] poměr manželů je velmi svobodný; někteří srozuměvše se, žíjou každý v jiném poměru, jiní zase se rozejdou [...]. Vůbec je obcování mužského pohlaví s ženským velmi svobodné a konversace vede se ve společnostech někdy tak závadná, že by paní $\mathrm{z}$ auslandu neslušností, ne-li hưře, nazvala ten zvyk zakořeněný, jenž nikomu zde nezdá se být hříchem (Němcová 1955, s. 45).

Warto odnotować, że narratorka nie dokonuje w tym przypadku już tak surowych ocen. Luźniejsze obyczaje w sferze intymnej nie wydają jej szczególnie gorszące, a można nawet powiedzieć, że uświadamia sobie wymiar kulturowego konstruktywizmu w tej sferze ludzkiego życia. Skoro bowiem w innej kulturze kwestie swobody w relacjach intymnych nie są traktowane jako grzech, to może należy restrykcyjny stosunek do nich poddać rewizji. Jest to jedyny przypadek, kiedy węgierskie normy kulturowe wydają się stanowić dla Němcovej rodzaj inspiracji.

\section{Niechęć do przeprowadzki}

Przedstawiłem powyżej ogólny stosunek pisarki do Węgier, gdzie miała się przeprowadzić z Czech. Powodów sprzyjających podjęciu takiej decyzji trudno się w relacji podróżniczej i korespondencji Němcovej doszukać. Kraj ten nie jawi się z pespektywy mieszkanki zaawansowanych cywilizacyjnie Czech jako miejsce, w którym chciałby się osiedlić na stałe z rodziną. Dlatego też w jej działaniu nie widać specjalnego pośpiechu w celu dołaczenia do męża. Stan zawieszenia trwał, jak już wspominałem, ponad dwa lata, a pisarka ostatecznie podjęła decyzję o przeprowadzce z młodszymi dziećmi dopiero w 1853 roku.
Na podstawie wyłaniającego się z jej korespondencji i dziennika podróży stosunku do Węgier można wywnioskować, że charakter nowego miejsca stanowił jeden z głównych powodów, dla których zwlekała. Nigdzie jednak nie zostało to wypowiedziane wprost. Niechęć do Węgier ujawnia się w sposób nie w pełni uświadamiany poprzez zablokowanie literackiej weny twórczej oraz w reakcjach psychosomatycznych. W liście z września 1852 roku wysłanym z Balašskich Ďarmot do Žofii Rottovej pisze:

Já nevím, zde nemám žádné krásné básnické sny, ale jako že může být mysl básnická, když musím jíst [...] sama taková hloupá jídla, zvlášt’ když k tomu ještě bob přidám. Věru byl by čas, abych se vrátila k mé pražské stravě (Němcová 2003, s. 257).

Z kolei w liście do małżonków Hanušovych wysłanym już po przeprowadzeniu się na stałe w 1853 narzeka na stan zdrowia, który po przyjeździe znacznie się pogorszył:

Těšila jsem se, že mi ten uherský vzduch půjde k duchu a že se trochu zotavím, ale naděje mne zmýlila. Ještě jsem neměla zde hodinu spokojenou, nejenom že mám ustavičně $\mathrm{v}$ žaludku křeče a bolesti v levém boku že se s obvyklou neústupností vrátili (Němcová 2004, s. 40-41).

Badany materiał zawiera jednak ślady zwerbalizowanych powodów niechęci Němcovej do opuszczenia Czech. Można je podzielić zasadniczo na dwa typy: powód oficjalny, wyrażony wprost, i powód ukryty, który jest w oficjalnej wersji utajony i udało się go zrekonstruować na podstawie intymnej korespondencji pisarki. Tym pierwszym powodem jest powoływanie się na dobro dzieci, którym powinno się zapewnić dobrą edukację. Němcová w korespondencji z przyjaciółmi podkreśla wielokrotnie, że na Węgrzech są wyłącznie szkoły węgierskie (Němcová 2003, s. 214). Ze zrozumiałych patriotycznych względów jej dzieci wyłączone zostałyby z czeskiego procesu edukacyjnego, którego była przecież zagorzałą orędowniczką. Co chyba jednak gorsze, nie byłyby nawet objęte kształceniem w uniwersalnym języku monarchii, czyli niemieckim. Oznaczałoby to ich całkowita marginalizację oraz zamknięcie wielu ścieżek potencjalnej austriackiej kariery zawodowej. Edukacja w języku węgierskim, kompletnie z punktu 
widzenia ich rodziców nieprzydatnym, byłaby działaniem na szkodę. Nie jest to jednak jedyna przyczyna niechęci do szkół węgierskich. Większy problem stanowił fakt, że było one albo kościelne, albo nauczali w nich katoliccy duchowni, o których Němcová miała jak najgorsze zdanie, czemu dała wyraz w liście do Antonína Klementa z czerwca 1851 roku (,[...] v gymnázium jsou profesoři františkáni, náramní hlupáci”; Němcová 2003, s. 187).

Drugim i zarazem ukrytym powodem wydaje się być zdobycie przez Němcovą znacznej swobody w związku z wyjazdem męża. Josef Němec nie stanowił dla pisarki w tym czasie już inspirującego partnera zarówno pod względem intymnym, jak też intelektualnym. W każdym bądź razie w korespondencji z interesującego nas okresu natrafiamy na bardzo intymne listy Němcovej adresowane do mieszkającego na Morawach Jana Helceleta, doktora nauk medycznych i przyrodniczych. Wynika z nich, że pisarkę w 1851 roku łączyła z Helceletem forma relacji miłosnej i nieobecność męża zdecydowanie ułatwiała jej podtrzymywanie. W liście z sierpnia 1851 roku pisze na przykład:

Jen to bylo by mi nemilé, kdybyste se s Němcem zde setkali. [...] (Němcová 2003, s. 190),

natomiast $\mathrm{w}$ liście $\mathrm{z}$ grudnia tego samego roku go prosi:

Nepiš mi ted' stranu té mé otázky nic, nebot' mám ve zvyku, když muž je doma, dávat mu moje listy číst (Němcová 2003, s. 220).

Uproszczeniem byłoby jednak sądzić, że chodzi wyłącznie o przestrzeń potrzebną do nieskrępowanego kontynuowania romansu lub innej formy zażyłości intymnej. Sądzę, że bardziej chodzi tu o ogólne poczucie wolności od małżeństwa, w którym żyła już od czternastu lat. Z listu do sióstr Rottovych z września 1851 roku dowiadujemy się, że Němcová spędza z dziećmi letnie wakacje w górach w okolicach Českiej Třebovej we Wschodnich Czechach. Z tonu listu nie wynika, żeby wolny czas zamierzała poświęcić kolejnej wizycie u męża na Węgrzech. Wręcz przeciwnie, wydaje się, że jest na łonie przyrody przeszczęśliwa, przede wszystkim ze względu na spokój i odczuwaną wolność:

[...] pomyslete, co já tu všecko mám. Hory, lesy, rozkošné vyhlídky, vodu jako krystal, lázně, samotu; spravedlivou smetanu, dobrý chléb s chutným máslem [...] po jídle čte se v lese výborná nějaká kniha [...]. A tak máme všecko, věřte, moje drahé (Němcová 2003, s. 211).

Jeżeli zestawimy te fragmenty korespondencji z dość empatycznym opisem węgierskich obyczajów w zakresie pożycia małżeńskiego, zrozumiemy, że z raz zdobytej wolności trudno było jej zrezygnować.

\section{Konkluzja}

Doświadczenie, może nawet nie tyle samej emigracji, co raczej konfrontacji z potencjalna emigracja i nowa przestrzenią kulturową, było z pewnością istotnym czynnikiem nabywania przez pisarkę podmiotowej samoświadomości. Można chyba zaryzykować twierdzenie, że pozwoliło jej ono zrewidować własny stosunek do propagowanego przez czeski dyskurs narodowy modelu kobiecej tożsamości. Przede wszystkim zetknięcie się z bardziej zapóźnionymi cywilizacyjnie Węgrami mogło umocnić w niej potrzeby intelektualno-duchowej emancypacji i niezależności, umacniane przez etnocentryczne przekonanie o własnej wyższości cywilizacyjnej. To ostanie odczucie dość wyraźnie ujawnia się w protekcjonalnym ocenianiu stosunku Węgierek do prowadzenia gospodarstwa domowego, chociaż sama tego „kobiecego” zadania ewidentnie nie lubiła. Znacznie ważniejsze wydaje się jednak zdobycie określonej sfery wolności od męża i przestrzeni do samorealizacji, poddające rewizji model czeskiej patriotki jako strażniczki domowego ogniska.

\section{Źródła}

N ě m cová Božena, 2003, Korespondence I 1844-1852, opracowanie Robert Adam et al., Praha: Nakladatelství Lidové noviny. 
Ně m c ová Božena, 2004, Korespondence II 1853-1856, opracowanie Robert Adam et al., Praha: Nakladatelství Lidové noviny.

N ě m c o v á Božena, 1955, Národopisné a cestopisné obrazy ze Slovenska, opracowanie František Váhala, Praha: SNKLHU.

S v ět l á Karolína, 1880, Z literárního soukromí, „Ženské listy”, nr 8, s. 50, 78, 96, 107, 125-141, 159, 175, 191.

\section{Literatura}

B a d in te r Elisabeth, 1998, Historia miłości macierzyńskiej, przeł. K. Choiński, Warszawa: Oficyna Wydawnicza Volumen.

B 1 o m Ida, H a g e m a n n Karen, H a 11 Catherine (red.), 2000, Gendered Nations. Nationalism and Gender Order In the Long Nineteenth Century, Oxford New York: Oxford University Press.

Do minte Carmen, 2016, Travel writings as means of intercultural translation, "Metacritic Journal for Comparative Studies and Theory", nr 1, s. 139-154.

F i 1 i p o w i c z Marcin, 2008, Urodzić naród. Z problematyki czeskiej i stowackiej literatury kobiecej XIX wieku, Warszawa: WUW

Frajk ovská Jana, 2011, Po stopách pobytů Boženy Němcové, Praha: J. Frajkovská.

H a 1 u z n i c ký Bohumil, 1952, Božena Němcová a Slovensko, Bratislava: Tatran.

H r o c h Miroslav, 2009, Národy nejsou dílem náhody. Př́činy a předpoklady utváření moderních evropských národi̊, Praha: SLON.

Johnst on e William M., 1983, The Ausrian Mind. An Intellectual and Social History 1848-1939, Berkeley-Los Angeles-London:University of California Press.

Kozicka Dorota, 2003, Wędrowcy światów prawdziwych. Dwudziestowieczne relacje z podróży, Kraków: Universitas.

L e e r s e e n Joep, 2006, National Thought in Europe. A Cultural History, Amsterdam: Amsterdam University Press.

L o u ži 1 Jaromír, 2005, K zápasu o J. G. Herdera u nás, „Česká literatura“, nr 5 , s. $637-653$.

P o k o r n á Magdaléna, 2004, Předmluva, [w:] Němcová Božena, Korespondence II 1853-1856, opracowanie Robert Adam et al., Praha: Nakladatelství Lidové noviny. 